\title{
Model Development of Non-Destructive Coffee Beans Moisture Content Determination Using Modified Near Infrared Spectroscopy Instrument
}

\author{
Rizky Wiradinata $^{\left.1^{*}\right)}$, I Wayan Budiastra ${ }^{2)}$, and Slamet Widodo ${ }^{2)}$ \\ ${ }^{1)}$ Indonesian Coffee and Cocoa Research Institute, Jl. PB Sudirman 90, Jember, Indonesia \\ ${ }^{2)}$ Faculty of Agricultural Technology, IPB University, Kampus IPB Dramaga, Bogor, Indonesia \\ *Corresponding author: rizky.wirad@gmail.com \\ Received: 10 May 2021 / Accepted: 2 November 2021
}

\begin{abstract}
A method of non-destructively moisture content measurement of coffee beans is using near infrared spectroscopy (NIRS) which in general can be applied to determine chemical content of various organic materials. However, the commercial NIR instrument can not measure many samples in a single time, consequently the faster measurement can not be realized. The purposes of this research was to study the performance of modified NIR instrument prototype for measuring the moisture content of Java Preanger coffee beans. Performance study of modified NIR instrument was carried out on 50 coffee bean samples for determination of sample moisture content. The reflectance spectra of samples were measured by modified NIRS instrument and then water content of samples was determined by oven method. The spectra data and water content were calibrated by multiple linier regression method to find the best calibration model. The result of this research show that number of wavelengths chosen to predict the moisture content of Java Preanger coffee bean accurately is 17 wavelengths. The correlation coefficient $(\mathrm{R})$ moisture content based on NIRS instrument and oven method was 0.902 , this suggest that the model is able to explain $90.2 \%$ the diversity of existing data. The value of standard error calibration (SEC) and standard error prediction (SEP) was almost zero meaning that the error of prediction is low. This study also reveal that the value of residual predictive deviation (RPD) is 2.32 , which means the prediction model for determination of Java Preanger coffee beans moisture content is good enough.
\end{abstract}

Keywords: coffee beans, NIR, NIRS instrument, moisture content

\section{INTRODUCTION}

Moisture content is related to the storage period of coffee beans and for preventing discoloration of coffee beans, the growth of fungi and other microorgamisms (Novita et al., 2010). Very low content of coffee moisture (below 9\%) will cause damage in taste and color (Sivetz \& Desrosier, 1979). The measurement of coffee bean moisture content is very important and should not be missed in postharvest handling. There are many methods used to measure the moisture content of coffee beans, which in general can be divided into two, namely destructive and non-destructive. Destructive method is carried out by destroying the sample, consequently it take quite longer time and can potentially be contaminated by microorganisms. The non-destructive method is carried out without destroying the sample. A certain nondestructive metod is faster than destructive method and utilize sound media, radiation, electromagnetic waves and optics (Livingstone, 
2001). One way to determine coffee bean moisture content non destructively is by using NIR wave which is the wavelength range of 780-2500 $\mathrm{nm}$. NIR can be used to determine the chemical content of organic materials because the molecular bonds of organic matter are very sensitive to this wavelength (Mardison, 2010). The molecules of organic matter can vibrate when interacting with NIR waves due to the displacement of atoms towards or away from one another (Ayu, 2017). A device that use NIR waves is called NIR spectroscopy (NIRS) instrument. One of the most development principles of NIRS instrument is dispersive instrument, where the NIR waves is passed through prism or grating (Murray \& Williams, 1990). The NIR waves refracts inside the prism, so that wavelength coming out of prism is a single wavelength then passed through the sample. The changing position of prism cause a changed angle of wave coming out from the prism (Kunlestiowati, 2016).

One of the NIRS instruments used to determine the chemical content of organic material is FT-NIR Spectrometer, type NIRFlex N-500 (BUCHI Labortechnic, Switzerland). It takes a long time to measure samples using the FT-NIR spectrometer because it must be placed one by one into the sample holder (the data collection speed of the NIRFlex N-500 is 2-4 scans.sec ${ }^{-1}$ ). Ayu (2017), used the NIRFlex N-500 to determine the caffeine, trigonelline, and chlorogenic acid (CGA) of 100 green bean samples of Java Preanger coffee. Each sample was scanned with a wavelength in the range of 1000 $2500 \mathrm{~nm}$ (1500 wavelength scan) for each measurement. Therefore, the time required to perform a wavelength scan was approximately 13.8 hours, not including adding and removing samples. This issue can be solved by using a NIRS instrument based on a grating monochromator and filters (Budiastra et al.,
1998). The grating monochromator changes the NIR wavelength to a single wavelength, and the filter limits the NIR wavelength which was used to determine chemical content of organic matter, therefore spectral data collection can be done more quickly. However, the samples to be measured are placed one by one in the sample holder, which is difficult to operate the tool. Wiradinata et al. (2019) modified the constituent units of NIRS instruments such as optical, electronic units and a mechanical unit (auto-sample holder) was also added to the instrument. The modified NIRS instrument can accommodate more than one sample and perform measurements automatically on the samples. It also has a faster data retrieval speed than the NIRFlex N-500.

The research of using NIRS instrument on coffee beans has been done, but the NIRS instrument are limited to FT NIR Spectrometer. The different instrument will result in different mathematical model to determine the chemical content of organic matter. The objective of this research was to study the performance of modified NIRS instrument prototype for measuring the moisture content of Java Preanger coffee beans.

\section{MATERIALS AND METHODS}

This study used a modified NIRS instrument (Wiradinata et al., 2019). The materials used were green beans of Java Preanger coffee obtained from the Indonesian Coffee and Cocoa Research Institute (ICCRI). The data collection method consisted of sample preparation stage, NIR spectrum data collection, measurement of the moisture in oven method based on Indonesian National Standard for coffee beans, SNI 01-2907-2008, calibration, and validation. As many as 50 samples of grade I mediumsized green beans were prepared with an average weight of $30 \mathrm{~g}$. In NIRS instrument 
measurement, the stacks of samples affect the resulting spectrum. The best number of stacks is five stacks (Madi, 2018). The sample holder on the NIRS instrument used in this study is a cylinder with diameter of $5 \mathrm{~cm}$ and height of $2 \mathrm{~cm}$. With that size, the instrument can accommodate $30 \mathrm{~g}$ of Java Preanger coffee green beans with an average of 5 stacks.

\section{NIR Spectrum}

Before measuring the NIR spectrum, the white standard or white reference spectrum was measured first. The data collection for the NIR spectrum and the white standard was only carried out in the wavelength of 900-1400 nm based on the signal-to-noise ratio or $\mathrm{S} / \mathrm{N}$ of the modified NIR instrument. The $\mathrm{S} / \mathrm{N}$ ratio of this wavelength range was higher than the other wavelength ranges. This was evidenced by the smoothness of the spectrum obtained. The white standard data and samples generated from the modified NIRS instrument were electrical voltage in millivolts $(\mathrm{mV})$. Therefore, the two data had to be compared to obtain the reflectance $(\mathrm{R})$ value. The calculation of white standard data and samples to obtain Reflectance $(R)$ and Absorbance (A) values is presented in Equations 1 and 2.

$R=\frac{V_{s}}{V_{w-s}}$

$A=\log \left(\frac{1}{R}\right)$

Where:

$$
\begin{array}{ll}
R & =\text { Reflectance } \\
V_{s} & =\text { The voltage of sample }(m V) \\
V_{w s} & =\text { The voltage of white standard }(m V) \\
A & =\text { Absorbance }
\end{array}
$$

\section{Oven Method}

The measurement of the moisture of Java Preanger coffee green beans began with drying an empty cup in an oven at $105^{\circ} \mathrm{C}$ $\pm 1^{\circ} \mathrm{C}$ for 1 hour. Then, the beans were cooled in a desiccator until they reached room temperature and weighed for their empty weight. The sample which spectrum data had been measured was put into a cup (10 g.cup ${ }^{-1}$ with an accuracy of $0.1 \mathrm{mg}$ ), brought into oven at temperature of $105^{\circ} \mathrm{C} \pm 1^{\circ} \mathrm{C}$ for 16 hours \pm 1 hour, and then weighed again. The value of moisture $(\mathrm{Ka})$ as weight loss is calculated using Equation 3.

$K a=\frac{m_{1}-m_{2}}{m_{1}-m_{0}} \times 100 \% \ldots \ldots \ldots \ldots \ldots \ldots$ (3)
$m_{0}:$ Empty weight of the cup (g)
$m_{1}:$ Cup and sample weight before being put into the oven (g)
$m_{2}:$ Cup and sample weight after being put into the oven (g)

\section{Calibration}

The data obtained from NIRS instruments cannot explain chemical information directly. Therefore, a method is needed to change that information through a calibration procedure by describing the mathematical relationship between the NIR spectrum and chemical content parameters (Athfiyah, 2017). One of the NIR spectrum calibration methods is multiple linear regression (MLR) which is a linear regression method used to show the correlation between one dependent variable and several independent variables. With this method, the dominant wavelength of a particular chemical content can be determined. However, this method needs more samples to perform the analysis (Ayu, 2017). The calculation to estimate the concentration of chemical content of the material can refer to Equation 4.

$$
Y=a+b_{1} x_{1}+b_{2} x_{2}+\cdots+b_{k} x_{k} \cdots
$$

Where:

$$
\begin{array}{ll}
Y & =\text { Moisture content of the sample } \\
a & =\text { Constant } \\
b_{1,2, \ldots k} & =\text { Regression coefficient } \\
x_{1,2, \ldots k}= & \text { Regression factor (absorbance at different } \\
& \text { wavelengths) }
\end{array}
$$

The first step in MLR calibration is to select the dominant wavelength with the same 
characteristics as the reference wavelength (958 nm) using Minitab 18 software. In the next step, stepwise multiple linear regression (SMLR) was carried out to choose a $\log$ value $(1 / R)$ at a specific wavelength. This was done to get one of the best calibration values as an independent variable. Then, we looked for the next $\log$ value $(1 / \mathrm{R})$ at another wavelength as the second variable (second regression factor) in two regression times and continued until it reached a satisfactory criterion. The last step was to analyze the accuracy of the selected waves using the Unscrambler X software.

After the calibration model was obtained, the accuracy of the model in predicting the moisture of Java Preanger coffee green beans was evaluated or validated. Mouazen et al. (2005) state that the accuracy and precision of the NIRS method in predicting the chemical components of beans can be retrieved from the correlation coefficient (R), calibration error standard (CES), prediction error standard (PES), coefficient of variation (CV), and residual predictive deviation (RPD) or the ratio of standard deviation to PES. The correlation coefficient (R) shows the ability of the model (mathematical equation) to explain the value diversity of independent variables. The range of R-values is 0 to 1 -the greater the $\mathrm{R}$-value, the more accurate the model. Equation 4 shows the calculation of the R-value.

$R=\frac{\sum\left(x_{n}-z_{n}\right)\left(Y_{n}-P_{n}\right)}{\sqrt{\Sigma\left(X_{n}-I_{n}\right)^{2} \sum\left(Y_{n}-Y_{n}\right)^{2}}}$.

Where :

$X_{n}$ = moisture data (oven method)

$\bar{X}_{n}=$ average of moisture data (oven method)

$Y_{n}$ = predicted moisture data (NIRS)

$\bar{Y}_{n}=$ average of predicted moisture data (NIRS)

The standard error (SE) is the difference between the reference moisture (oven method) and the predicted moisture (NIRS). The smaller the SE value (closer to zero), the better the model. The method to calculate the SE value is shown in Equation 5.

$S E=\sqrt{\frac{\sum\left(Y_{\text {NIRS }}-Y\right)^{2}}{n}}$

Where:

$$
\begin{array}{ll}
Y_{\text {NIRS }} & =\text { predicted moisture (NIRS) } \\
Y & =\text { moisture of oven method } \\
n & =\text { number of samples }
\end{array}
$$

The calibration error standard (CES) indicates the accuracy of the calibration equation obtained, whereas the prediction error standard (PES) points out the accuracy of the validation model. The smaller the CES and PES values, the smaller the error level in the calibration and validation equations. CES and PES values must be close to zero; the range between the two is the measurement consistency with the obtained equation, which is $80-100 \%$ (Buchi, 2013).

The coefficient of variation (CV) compares the diversity of two data groups whose value range is very contrasting. The $\mathrm{CV}$ value is the ratio between the error standard and average moisture data (oven method). Equation 6 demonstrates the calculation of the $\mathrm{CV}$ value.

$C V=\frac{S E}{B} \times 100 \%$

$\mathrm{SE}=$ standard of error

Residual Predictive Deviation (RPD) is the ratio between the standard deviation of chemical data (moisture) and PES. RPD values in the range of 1.5-1.9 indicate rough predictions so that the calibration needs improvement. On the other hand, RPD values in the range of $2-2.5$ show a fairly good predictive model, while above 2.5 represent a very good predictive model (Mouazen et al., 2005). Equation 7 below shows the formula to calculate the RPD value.

$\mathrm{RPD}=\frac{\mathrm{SD}}{\mathrm{PES}}$

$\mathrm{SD}=$ standard deviation 


\section{RESULTS AND DISCUSSION}

Figure 1 displays the original absorbance spectrum of Java Preanger coffee green beans in the wavelength range of 900 $1400 \mathrm{~nm}$ with a total of 500 spectrum data. The figure shows the presence of absorption peaks and valleys. Generally, all tested samples have the same graphic pattern. This indicates that the NIR instrument is able to provide consistent measurement results. The shape of the spectrum is influenced by the instrument used, the size of the sample particle, the concentration of chemical constituents in the sample, and the wavelength used. The larger the particle size of the sample, the greater the concentration in the material. Therefore, it will create a larger NIR absorbance spectrum. This causes the absorption peak of the content appear in the original spectrum.

The sample used in this study was green beans of Java Preanger coffee with a moisture level of $10-12 \%$. The peaks of moisture absorption of the grains (as agricultural materials) are at the wavelengths of $958 \mathrm{~nm}, 1450 \mathrm{~nm}, 1910 \mathrm{~nm}$, and $2510 \mathrm{~nm}$ (Bertand et al., 1985). According to Zhang et al. (2013), the moisture in the material can affect the shape of the spectrum because moisture is the main component of biological materials. This has caused the absorption peak (absorbance) of the moisture to appear at the peak of the original spectrum wave. Therefore, the determination of the moisture can be carried out without pre-processing the spectrum data (Ayu, 2017). However, due to a large amount of noise in the original NIR absorbance spectrum data used a modified NIRS instrument, the data had to go through the initial spectrum data processing. Noise is caused by the not-large-enough amplification of an amplifier's sensor output signal. In this study, the noise can be seen in the uneven wave fluctuation. Noise can be overcome by processing the initial spectrum data through smoothing with the MovingAverage method. The results of the initial data processing are shown in Figure 1.

Another factor that affects the shape of the NIRS absorbance spectrum is the NIRS instrument used. The modified NIRS instrument used in this study was a $\mathrm{Pbs}$ sensor with a sensor output signal amplification in the form of an AT100AP amplifier. In addition, the data generated by this NIRS instrument was influenced by halogen lamps and integrating sphere. All the resulting graphs had large fluctuations, indicating high noise. As explained before, noise is caused by the not-large-enough amplification of an amplifier's sensor output signal. After the data collection for the basic performance of the NIR instrument was completed, the AT100AP amplifier was damaged because the supply voltage to the amplifier was too high. The signal amplification, which was set 200 times larger (gain 200) by the manufacturer as the operational standard for using NIRS instruments, produced incorrect data. The solutions to overcome noise can be done by improving the amplifier and/or adding a series of lowpass and highpass filters.

The calibration and validation results of Java Preanger coffee green beans moisture are shown in Table 1. The MLR method allows us to determine the most dominant wavelength in predicting moisture. The dominant wavelength was obtained by entering a reference wavelength $(958 \mathrm{~nm})$. Then, the MLR method (stepwise regression type) will look for other wavelengths among the reference wavelengths to produce the largest $\mathrm{R}$-value.

Table 1 shows that the most dominant wavelength in predicting moisture content of Java Preanger coffee green beans using a modified NIRS instrument is 17 wavelengths with the reference wavelength of $958 \mathrm{~nm}$. Table 1 shows that the CES value is $0.191 \%$ 

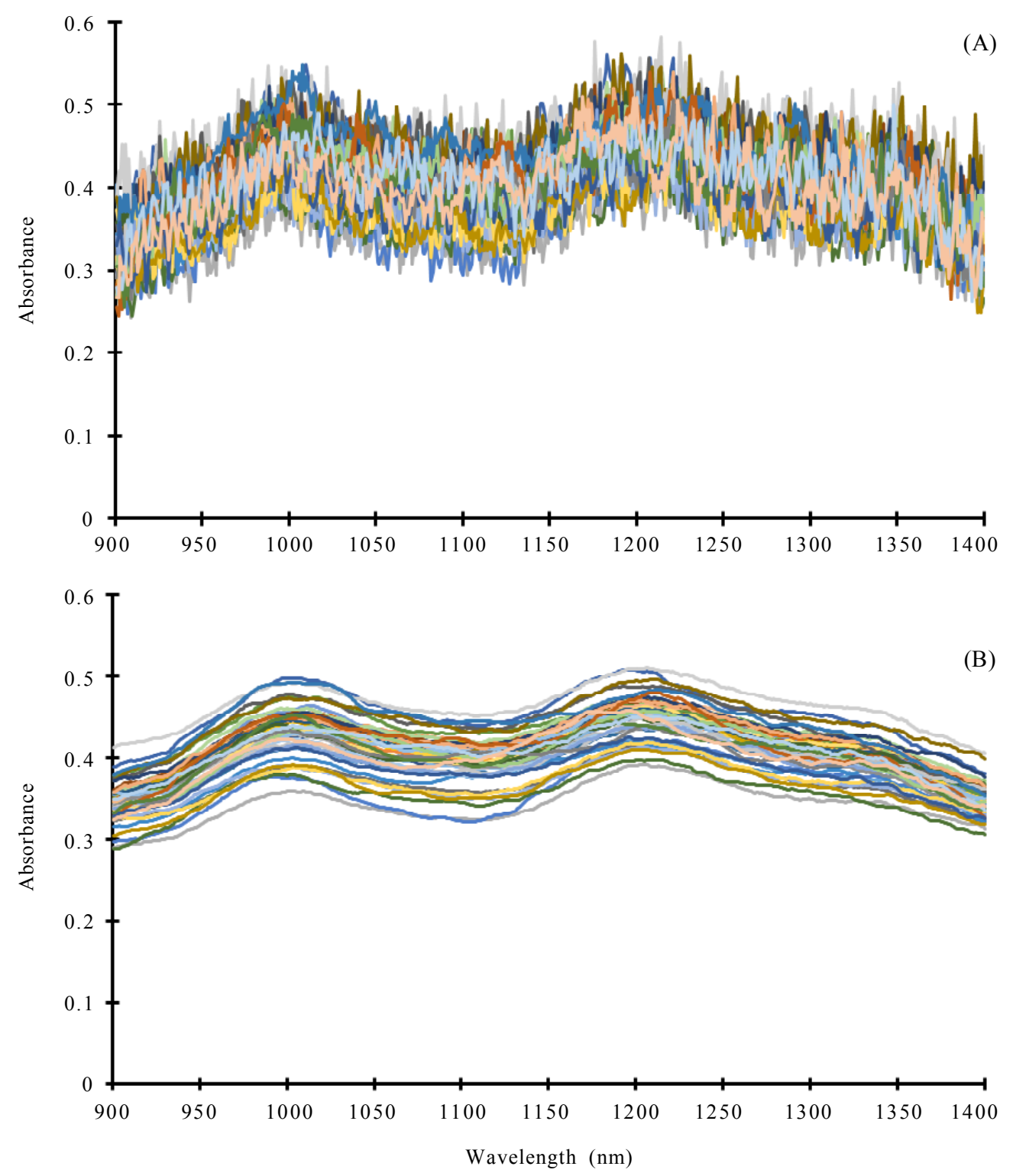

Figure 1. Relationship between absorbance and wavelength $(\mathrm{nm})$ of 50 samples of Java Preanger coffee green beans in the original spectrum (A) and after smoothing (B)

while the PES is $0.482 \%$. These values are close to zero, which means that the equation model generated from the calibration process can be used to determine the moisture of Java Preanger coffee green beans due to a low error rate. The consistency of the model in predicting the moisture is $39.50 \%$. This can be improved if the initial processing of spec- trum data is correct. The RPD value obtained is 2.32 , which means that the prediction model obtained is quite good because it is in the range of 2-2.5. Nevertheless, further improvements are still needed. The MLR equation model for predicting the moisture of Java Preanger coffee green beans using the modified NIRS instrument is presented in Equation 8. 
Table 1. List of selected wavelengths and validation results

\begin{tabular}{|c|c|c|c|c|c|c|}
\hline Selected wavelengths (nm) & $\mathrm{R}$ & $\begin{array}{l}\text { CES } \\
(\%)\end{array}$ & $\begin{array}{l}\text { PES } \\
(\%)\end{array}$ & $\begin{array}{l}\text { CV } \\
(\%)\end{array}$ & RPD & $\begin{array}{c}\text { Consistency } \\
(\%)\end{array}$ \\
\hline $\begin{array}{l}937 ; 953 ; 958 ; 975 ; 992 ; 995 ; \\
1030 ; 1069 ; 1071 ; 1072 ; 1091 ; \\
1102 ; 1153 ; 1181 ; 1182 ; 1197 ; \\
1210\end{array}$ & 0.90 & 0.19 & 0.48 & 4.21 & 2.32 & 39.50 \\
\hline
\end{tabular}

$\mathrm{Y}=13.098+(2.593 \times \mathrm{A} 937)+(1.499 \times$

A953) - $(4.806 \times \mathrm{A} 958)+(0.356 \times \mathrm{A} 975)$

$-(3.709 \times \mathrm{A} 992)+(0.770 \times \mathrm{A} 995)-$

$(0.622 \times \mathrm{A} 1030)-(4.757 \times \mathrm{A} 1069)+$

$(0.344 \times \mathrm{A} 1071)-(0.400 \times \mathrm{A} 1072)-$

$(2.966 \times \mathrm{A} 1091)+(0.482 \times \mathrm{A} 1102)+$

$(1.886 \times \mathrm{A} 1153)+(1.120 \times \mathrm{A} 1181)+$

$(0.123 \times \mathrm{A} 1182)-(0.660 \times \mathrm{A} 1197)-$

$(3.524 \times \mathrm{A} 1210)$

Equation 8 shows NIR wave absorbance data at 17 selected wavelengths are required $(937 \mathrm{~nm}, 953 \mathrm{~nm}, 958 \mathrm{~nm}, 975$ nm, 992 nm, 995 nm, 1030 nm, 1069 nm, 1071 nm, 1072 nm, $1091 \mathrm{~nm}, 1102$ nm, 1153 nm, $1181 \mathrm{~nm}, 1182 \mathrm{~nm}, 1197 \mathrm{~nm}$, and $1210 \mathrm{~nm}$ ) to predict the moisture of green coffee beans with the modified NIRS instrument. The determination of the selected wavelength and constant is done by the MLR method using Minitab 18 software. The software will select a wavelength with the same characteristics as the reference wavelength (958 nm) and arrange it into a mathematical equation model to predict the moisture of Java Preanger coffee green beans. After knowing the equation model, the next step is to evaluate the equation by comparing the results of the moisture prediction using the modified NIRS instrument and the oven method (SNI 01-2907-2008).

Figure 3 shows the relationship of moisture prediction of Java Preanger coffee green beans with the modified NIRS instrument and the oven method. Many parameters can be used to evaluate the performance of the modified NIRS instrument and the obtained calibration equation, one of which is the value of the correlation coefficient (R). The R-value of the moisture prediction using the modified NIRS instrument and the oven method is 0.74 . The $\mathrm{R}$-value indicates that the value of moisture prediction by the modified NIRS instrument has a fairly strong relationship with the moisture by the oven method. Therefore, the equation obtained through the MLR calibration above can be used to predict the moisture by the modified NIRS instrument. The time required to perform wavelength scan, of the modified NIRS instrument only 1.7 minutes per sample compared with NIR flex N-500 which need 8.4 minutes (Ayu, 2017).

Other research than coffee green beans has predicted the moisture of agricultural products using NIR wave. One of which is the examination of jatropha seeds conducted using the partial least square (PLS) method. The research produced an R-value of 0.96 (Lengkey et al., 2013). On the other hand, Ulva et al. (2016) also studied fine cocoa powder using the PLS method with pretreatment of mean centring and showed an R-value of 0.81. Still using the PLS method, Nurhasanah et al. (2019) focused on examining rice with pretreatment derivative- 1 and obtained an R-value of 0.92. Besides that, Sari et al. (2019) investigated grain moisture using the principal component regression (PCR) method with pretreatment de-trending and resulted in an R-value of 0.91. The moisture of Harum Manis mango was also tested using the PLS 


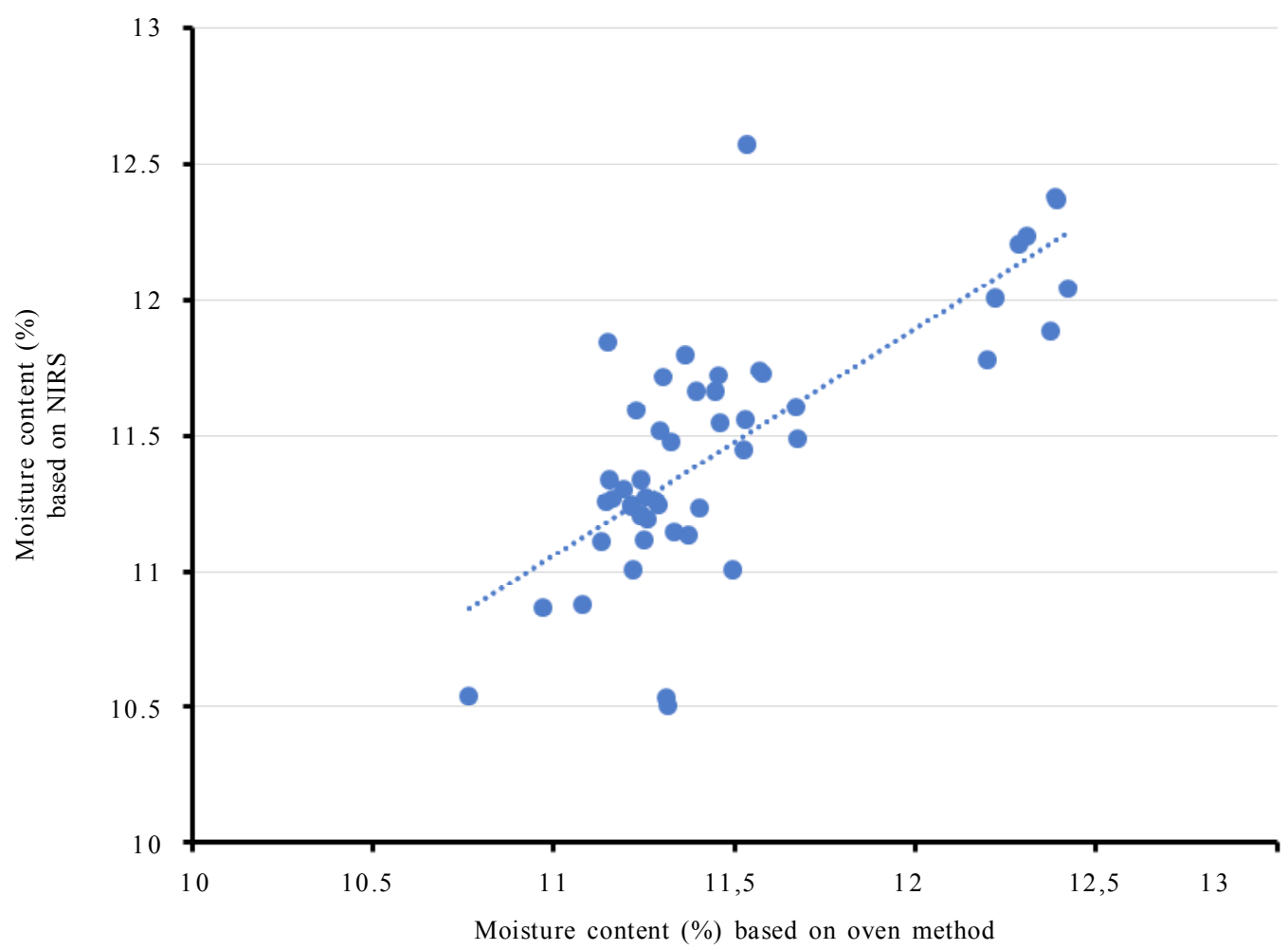

Figure 2. Relationship between the results of moisture prediction with modified NIRS instrument and oven method on the green beans of Java Preanger coffee

method with first degree pretreatment, resulting in an R-value of 0.88 (Agustina et al., 2019). Besides, observation on persimmon moisture was carried out using the PLS method and produced an R-value of 0.90 (Kurniasari, 2017). The previous studies used different data processing methods and NIRS instruments, resulting in different Rvalues. The $\mathrm{R}$-value of the modified NIRS instrument (0.74) is smaller than the R-values mentioned above. This happens due to a large amount of noise in the spectrum data. Further research is needed to determine the initial data processing method (pretreatment) and the appropriate calibration and validation method. In addition, further improvements in the amplifier and lowpass or highpass filters of the modified NIRS instrument also need to be done. Apart from these issues, modified NIRS instrument has the potential to be applied to the sorting system of agricultural products, considering that the current NIRS instrument in a laboratory is mostly fixed or unmodifiable.

\section{CONCLUSIONS}

The equation model to predict the moisture of Java Preanger coffee green beans using the modified NIRS instrument is obtained through the MLR method and pretreatment in Smoothing Moving-Average. The number of selected wavelength needed to build the equation is 17 , with a reference wavelength of $958 \mathrm{~nm}$. The obtained equation can predict the moisture of Java Preanger coffee green beans with calibration of 0.902 (correlation coefficient or R-value). The RPD value of 2.32 means that the equation to predict the 
moisture of Java Preanger coffee green beans is quite good but needs further improvement. The validation results show that moisture prediction using the modified NIRS instrument has a fairly strong relationship with the oven method, evidenced by the R-value of 0.742 . This value can be increased by overcoming noise in the amplifier circuit and performing an appropriate combination of pretreatment for the NIR spectrum data.

\section{ACKNOWLEDGEMENT}

We would like to thank Dr. Agung Wahyu Susilo, who provided guidance and the opportunity to publish this manuscript during the orientation and trial period. We also thank Dr. John Bako Baon, who has provided guidance and direction in writing this scientific paper.

\section{REFERENCES}

Agustina, S.; Y.A. Purwanto \& I.W. Budiastra (2015). Prediksi kandungan kimia mangga Arumanis selama penyimpanan dengan spektroskopi NIR. Jurnal Keteknikan Pertanian, 3, 57-63.

Athfiyah, S.N. (2017). Penentuan Kandungan Kimia Utama Biji Kopi Arabika Bondowoso Secara Non destruktif Dengan Near Infrared Spectroscopy. Skripsi. IPB University, Bogor, Indonesia.

Ayu, P.C. (2017). Pengembangan Model Penentuan Kandungan Kimia Utama Pembentuk Flavor Biji Kopi Java Preanger Menggunakan FT NIR. Thesis. IPB University, Bogor, Indonesia.

Bertrand, D.; P. Robert \& W. Loisel (1985). Identification of some wheat varieties by near infrared reflectance spectroscopy. Jounal of the Science of Food and Agriculture, 36, 1120-1124.

Buchi (2013). Nircal 5.5 Manual. Buchi Labortechnik. Switzerland.
Budiastra, I.W.; Y. Ikeda \& T. Nishizu (1998). Optical methods for quality evaluation of fruit (Part 1): Prediction of individual sugars and malic acid concentrations of apple and mangoes by developed NIR reflectance system. Journal of the Japanese Society of Agricultural Machinery, 60, 117-127.

Kunlestiowati, H.; N. Yuningsih \& W. Martono (2016). Penentuan sudut deviasi minimum prisma melalui peristiwa pembiasan cahaya berbantuan komputer. SIGMA$M u, 8,1-6$.

Kurniasari, I. (2017). Prediksi Kandungan Kimia Buah Kesemek (Diospyros kako L.) dengan Spektroskopi NIR. Skripsi. IPB University, Bogor, Indonesia.

Lengkey, L.C.E.CH.; I.W. Budiastra; K.B. Seminar \& B.S. Purwoko(2013). Model pendugaan kandungan air, lemak dan asam lemak bebas pada tiga provenan biji jarak pagar (Jatropha curcas L.) menggunakan spektroskopi inframerah dekat dengan metode Partial Least Square (PLS). Jurnal Littri, 19, 203-211.

Livingston, R.A. (2001). Nondestructive testing of historic structures. Archives and Museum Informatics, 13, 249-271.

Madi, S.C.Y. (2018). Analisis Variasi Jumlah Tumpukan Biji Terhadap Akurasi Prediksi Kandungan Minor Kopi Arabika dengan NIR Spectroscopy. Thesis. IPB University, Bogor, Indonesia.

Mardison (2010). Penentuan Komposisi Kimia Biji Jarak Pagar Secara Non Destruktif dengan Metode NIR dan Jaringan Saraf Tiruan. Thesis. IPB University, Bogor, Indonesia.

Mouazen, A.M.; W. Saeys; J. Xing; J. DeBaerdemaeker \& H. Ramon (2005). Near infrared spectroscopy for agricultural materials: An instrument comparison. Journal of Near Infrared Spectroscopy, 13, 87-97.

Murray, I. \& P.C. Williams (1990). Chemical principle of near-infrared technology. In: Near-Infrared Technology in the Agricultural and Food Industries. (P. Williams \& 
K. Norris, Eds). $2^{\text {nd }}$ Edition. American Association of Cereal Chemists. Minnesota.

Novita, E.; R. Syarif; E. Noor \& S. Mulato (2010). Peningkatan mutu biji kopi rakyat dengan pengolahan semi basah berbasis produksi benih. Jurnal Agroteknologi, $4,76-90$.

Nurhasanah; K. Siregar \& Zulfahrizal (2019). Prediksi kadar air beras menggunakan NIRS dengan metode PLS dan pretreatment standard normal variate, Derivative I, Savitzky Golay Smoothing. Jurnal Ilmiah Mahasiswa Pertanian, 4, 628-637.

Sari, M.; I.S. Nasution \& Zulfahrizal (2019). Prediksi kadar air gabah menggunakan Near Infrared Reflectance Spectroscopy dengan metode principal component regression (Pretreatment MSC, Second Derivative dan De-Trending). Jurnal Ilmiah Mahasiswa Pertanian, 4, 568-577.

Sivetz, M. \& N.M. Desrosier (1979). Coffee Technology. AVI Publ.Co. Westport, USA.
Ulva, C.M.; Zulfahrizal \& A.A. Munawar (2016). Prediksi kadar air bubuk biji kakao menggunakan NIRS dengan metode PLS. Jurnal Ilmiah Mahasiswa Pertanian Unsyiah, 1, 1037-1045.

Wiradinata, R.; I.W. Budiastra \& S. Widodo (2019). Modifikasi instrumen NIR untuk penentuan kandungan bahan organik secara cepat dan non destruktif. Jurnal Keteknikan Pertanian, 7, 49-56.

Zhang, X.; W. Li; B. Yin; W. Chen; D.P. Kelly; X. Wang; K. Zheng \& Y. Du (2013). Improvement of near infrared spectroscopy (NIRS) analysis of caffeine in roasted Arabica coffee by variable selection method of stability competitive adaptive reweighted sampling (SCARS). Spectrochimica Acta Part A: Molecular and Biomolecular Spectroscopy, 114, 350-356.

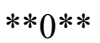

